and minimum inferior beat, in the same manner as the inferior beat is the result of the periodic recurrence of a maximum and minimum vibration.

Now, all inferior beats can be divided into two classes-similar and dissimilar beats. The four beats given by $\mathbf{3} 28$ vibrations, with 124 vibrations in the second, are perfectly similar beats, because the ratio $\frac{128}{124}$ is $\frac{4 \times 32}{4 \times 3 \mathrm{I}}$, i.e. the ratio in its simplest form is $\frac{32}{3 \mathrm{I}}$, giving one beat under precisely the same couditions of phase coincidence, at each.quarter of a second. But the four beats given by 127 vibrations, with 123 in the second, are dissimilar beats ; because the two S.H.M.'s, though together four times in the same phase in the second, these coincidences are at different parts of the wave-length ; just as the hands of a watch are twelve times together in one complete revolution of the hour hand, but at different parts of the dial.

Another example will complete my meaning. The example is an experiment described by Dr. Kœnig in his valuable work, "Expériences d'Acoustique," with the two tuning-forks making 75 and 40 vibrations in the second, English measure. Five distinct beats were heard along with the beat-sound of 35 beats in the second. Here we have the interval-ratio $\frac{75}{40}=\frac{5 \times 15}{5 \times 8}$ showing $(15-8)$ or 7 dissimilar beats recurring five times in the second. And we have apparently no other physical quantities to deal with. So that it appears a necessary conclusion that the seven dissimilar beats are in an undulatory order of intensity, in order to account for the five superior beats of Dr. Kœnig. The construction is then simple. Each recurrence of the 7 dissimilar beats is marked by a beat, and there are 5 of these in the second. These are the 5 superior beats formed out of the $5 \times 7$, or 35 inferior beats.

For this reason I have introduced the term cycle for the resultant generating curve formed by two S.H.M.'s of unequal periodic times. The curve or cycle is traced by the extremity of one generating radius revolving about the moving extremity of the other as a centre, and is complete when the two radii return to their original position. The cycle may be of long or short period. In the octave interval it is very short. With a nearly perfect unison it is very long. In every cycle there is at least one beat. There may be many dissimilar beats, but there cannot be any similar beats in the same cycle. The superior beat, number is, then, the number of cycles in the second; and the inferior beat-number is the product of the number of cycles into the number of dissimilar beats in the cycle.

According to this theory, therefore, the superior beats heard on the occasion referred to should be accounted for as follows:-

(I) When the two tuning-forks were executing 120 and 64 vibrations respectively in the second, eight superior beats were heard, because $\frac{120}{64}=\frac{8 \times 15}{8 \times 8}$ gives 8 cycles of 7 dissimilar beats, in each second of time.

(2) When the forks were making 96 and 64 vibrations, or the fifth interval, $3 / 2$, it would be more correct to say that there were no superior beats than to say that "the inferior and superior beats agree in frequency." Because the ratio $\frac{96}{64}=\frac{32 \times 3}{32 \times 2}$ shows 32 cycles of only one beat in each.

In like manner all the other experiments given in detail in the text of June ig (p. 190) can be accounted for. But there is an explanatory example given by Dr. S. P. Thompson, which, if verified by experiment, must be fatal to my theory of Kœnig's superior beats. This illustration gives 92 inferior beats and 8 superior beats in 492 and 100 vibrations of the primaries; while, according to the theory just sketched, $\frac{492}{100}=\frac{4 \times 123}{4 \times 25}$, shows only 4 superior beats with 392 inferior beats. Only Dr. Kœnig's valuable instruments could satisfactorily decide between then, and I should be glad to know if my building cannot stand. On the other hand, Dr. Molloy's elegant experiment, described in NATURE (vol. xlii. p. 246), is in favour of the cycles of dissimilar beats, inasmuch as these account for his three beats directly from the primaries without the aid of secondaries. In this experiment the primaries were 384 and 255 vibrations in the second; and the ratio $\frac{384}{255}=\frac{3 \times 128}{3 \times 85}$ shows 3 superior beats with 43 dissimilar beats in 129 inferior beats.

Stonyhurst College. WALTER SIDGREAVES.
THE CELL THEORY, PAST AND PRESENT. ${ }^{1}$

I.

$\mathrm{N}$ taking the chair at the first general meeting of the Scottish Microscopical Society, I would offer to the members my hearty thanks for having done me the honour to choose me as the President under whom the work of the Society is to be inaugurated, and during whose incumbency the Society is to begin to substantiate its claim to have an existence amongst the scientific Societies in Scotland.

As myself engaged in biological studies, it is only natural that my attention should have been more particularly directed to the use of the microscope in connection with them, and to the influence which it has exercised on their advancement. Since the time of Hooke, Grew, Malpighi, and Leeuwenhoek, this influence has been continuous and progressive. The improvements in the instrument during the present century have led to discoveries of the utmost value in the structure of plants and animals, and to generalizations of a wide-reaching importance.

One of, if not the most fundamental of these discoveries, was the recognition of the anatomical unit, which we call a cell, as a common element in the structure of organisms. Our conceptions of the structure of cells, of the relative function of their constituent parts, and the mode in which cells are developed and multiply, has varied very materially from time to time. I purpose to pass in review those aspects of the subject which have attained prominence, and have influenced the course of investigation.

Dr. Robert Hooke was one of the first men of science to employ the microscope in the study of the structure of plants and animals. A chapter in his "Micrographia" (London, 1665) is entitled "Of the Schematisme or Texture of Cork and of the Cells and Pores of some other such frothy Bodies." This is probably the first use of the word cell in histological description. In the course of this chapter he refers to the lightness of cork, which he compares with froth, or an empty honeycomb. Its substance, he says, is wholly filled with air, which "is perfectly enclosed in little Boxes or Cells distinct from one another." Further, he gives an idea of the dimensions of these cells by stating that about sixty could be placed endways in the $\frac{1}{18}$ th part of an inch, and that $1,166,400$ could be placed in a square inch. He thinks that they are the channels through which the juices of the plant are conveyed.

The term cell was also employed to express a definite morphological unit by Dr. Nehemiah Grew, ${ }^{2}$ who shares with Malpighi the glory of being one of the fathers of vegetable physiology. When describing in his "Anatomy of Plants" the skin of the root (p. 62), he says the parenchymous material is "frequently constructed of exceeding little Cells or Bladders, which, in some Roots, as of Asparagus,cut traverse, and,viewed through a Microscope, are plainly visible. These Bladders are of different sizes; in Buglos larger, in Asparagus less, and sometimes they coincide and disappear."

In his account of the parenchyma of the bark he again uses the word cells (p. 64), and says that "each is bounded within itself, so that the Parenchyma of the Barque is much the same thing as to its conformation, which the Froth of Beer or Eggs is as a fluid, or a piece of fine Manchet as a fixed body." These cells are so small as "scarcely, without the microscope, to be discerned ; " more usually, however, Grew applies to them the term bladders or vesicles. In the chapter on the vegetation of roots he speaks of the sap swelling and dilating the bladders, and

I The Inaugural Address delivered to the Scottish Microscopical Society, by Sir William Turner, F.R.SS. L. and E., President of the Society.

"The Anatomy of Plants," London, 2 nd ed., I682 'The several book into which Grew divided his treatise were presented to the Royal Society of London at various dates between $167 \mathrm{I}$ and 1675 . NO. IO97, VOL. 43] 
as being fermented therein, as transmitted from bladder to bladder, and leaving certain of its principles adhering to them. He thus recognized that the cells or bladders played an important part in the nutrition of the plant. Almost, indeed, he seemed to have grasped the idea that they exercised a selective or secreting influence; for, in describing the parenchyma of the fruit of the lemon, he speaks (p. I80) of "those little Cells which contain the essential Oyl of the fruit," whilst, he says, in other bladders "lies the acid juyce of the limon."

Malpighi, whose work on the anatomy of plants ("Anatome Plantarum," London, I675) was almost cotemporaneous with the treatise of Grew, had also seen the structures which Grew named cells or bladders, and had designated them utriculi, and believed that they could be separated from each other. In a subsequent treatise ("Opera," vol. ii. p. 4I, I686) he described the lobules of fat in animals as consisting of adipose vesicles.

Leeuwenhoek, in the course of his microscopic inquiries into the structure of plants, gave the name of globules to many of the objects which we now term cells, though he expressly states that they were not perfect spheres. ${ }^{1}$

Clopton Havers, in his treatise on the skeleton, described ("Osteologia nova," p. I67, I69I) the vesicular structure of the marrow, and compared it, when seen under the microscope, to a heap of pearls.

Alex. Monro, primus, in his work on the bones ("Anatomy of the Humane Bones," Edinburgh, Ist ed., 1726 ; 2nd ed., 1732), when writing on the medullary structure, stated that it is subdivided "into communicating vesicular Cells, in which the Marrow is contained. Hence it is that the Marrow, when hardned and viewed with a Microscope, appears like a Cluster of small Pearls. This Texture is much the same as what obtains in the other cellular parts of the Body where Fat is collected, only that the Cells containing the Marrow are smaller than those of the Tunica adiposa or cellulosa elsewhere."

Caspar F. Wolff ${ }^{2}$ also recognized that fat was contained in small vesicles, surrounded by a fine membrane. He conceived also that the developing organs, both of plants and animals, consisted of a viscous substance which contained cavities, cells, or bladders which communicated with each other.

Fontana figured the fat vesicles, both free and surrounded by the fibres of the areolar tissue. ${ }^{3}$

Mirbel, in his botanical writings, ${ }^{4}$ published at the beginning of the present century, stated that vegetables were composed largely of cells. He described le tissu cellulaire as composed of les cellules, which were contiguous with each other, so that the walls were in common. These walls were extremely thin and translucent, and sometimes riddled with pores. The term cells was also used both by his contemporaries and immediate successors in their writings on the anatomy of plants.

But anatomists experienced much greater difficulty in distinguishing the presence of cells in the textures of animals. It is true that from the time of Malpighi and Leeuwenhoek, the globules or particles had been recognized in the blood, but it is only within a comparatively recent period that their cellular structure was determined. Both Bichat ("Anatomie générale," Paris, I8I2) and Béclard ("Élémens d'Anatomie générale," Paris,

' Samuel Hoole, who translated many of Leeuwenhoek's writings (London, 1799, part 2, p. 178), when describing Fig. $x x$, on Pl. vi., says that the globules of meal are enclosed as it were in cells, and that some of those cells are represented at $\mathrm{H}$ in the figure. Leeuwenhoek, himself, however, in his description of the same figure " Epistolæ physiologicæ," Delphis, I7I9, p.

description of the same figure ("E
25), does not use the word cellula.

Nheoria Generationis," editio nova, 1774 ; Commentary " Ueber die Nutritionskraft," by Blumenbach and Born, St. Petersburg, 1789.

3 See his essay "Sur la structure primitive du corps animal" in his “Traité sur le vénin de la Vipère," Florence, I78r (Pl. viii., Figs. 19, 20). 4 " Traité d'Anatcmie et de Physiologie végétale," t. i., Paris. An. x. "Exposition de la Théorie de l'organisation végétale," Paris, r809. Ch. Robin, in the article "Cellule," "Dict. Encyclop. des Sciences médicales," Paris, 1873 , credits Mirbel with having introduced the term "cellules," but the extracts given in the text show that its English equivalent, cells, had been in use for upwards of a century before Mirbel wrote.
I823), in their important treatises on general anatomy, made no reference to cells as elements of the tissues. Both these authors had chapters du tissu cellulaire or $d u$ systeme cellulaire, a term which had been in use from the early part of the last century. But by the tela cellulosid or cellular tissue, anatomists meant that form of tissue which we now more appropriately call areolar tissue; the so-called cells of which are not microscopic closed vesicles, but areolæ or spaces bounded by the fibres or laminæ of which the tissue is chiefly composed. ${ }^{1}$ Béclard, in his description of the adipose tissue, stated that the lobules of fat consisted of microscopic vesicles $\frac{1}{100}$ to $8 \frac{1}{00}$ of an inch in diameter. The vesicles, he says, have walls, but they are so thin as to be indistinguishable. The presence of organized vesicles or globules in the tissues of animals had thus been recognized, but it needed further observations and facts in order to bring them into association with the cells of vegetable tissue.

This was supplied by the discovery in $183 \mathrm{I}$ by the great English botanist, Robert Brown, of the "nucleus" or "areola" in the cells of the epidermis, and other tissues in Orchideæ and many other families of plants." Following closely upon this discovery were the observations of Schleiden, published in I 838 ("Beiträge zur Phytogenesis," Miiller's Archiv, p. I37, 1838), that the nucleus was a universal elementary organ in vegetables. Schleiden also came to the conclusion that the nucleus must hold some close relation to the development of the cell itself, and he consequently called the nucleus a " cytoblast." "Schleiden further discovered that the cytoblasts contained one or more minute circumscribed "spots," or "rings," or "points," which he considered to be formed earlier than the cytoblasts, and which were regarded by him as hollow globules, and were subsequently named by Schwann "nucleoli."

The cellular structure of some of the animal tissues had also begun to be recognized. Turpin had noticed the resemblance between the epithelium corpuscles found in vaginal discharges and the cells of plants. Johannes Müller had discovered that the chorda dorsalis of fishes was composed of separate cells provided with distinct walls, though he did not detect a nucleus in them. Purkinje, Von Baer, Rudolph Wagner, Coste, and Wharton Jones had seen the germinal vesicle within the animal ovum. E. H. Schultz had observed the nucleus in the blood globules, and Valentin and Henle had seen it in the cells of the epidermis. The way was thus prepared for a fuller recognition of the essential correspondence between the elementary tissues of plants and animals and for a wider generalization. Science had not long to wait for an observer who could take a comprehensive grasp of the whole subject; and in 1839 Theodore Schwann published ${ }^{4}$ his famous researches into the structure of animals and plants, in which he announced the important generalization that the tissues of the animal body are composed of cells, or of materials derived from cells :-

"That there is one universal principle of development for the elementary part of organisms, however different, and that this principle is the formation of cells."

Both Schleiden and Schwann entertained the idea, which had long before been present in the mind of Grew, that a cell was a microscopic bladder or vesicle. In its typical shape they regarded it as globular or ovoid, though capable of undergoing many changes of form. This vesicle possessed a cell-membrane or wall, which enclosed

The term cellular tissue was originally applied to this texture from a fancied resemblance to the proper cell tissue of plants; the walls of the cells of which were believed to be formed of a framew, rk of fine fibres.

"Organs and Mode of Fecundation in (Jrchideæ and Asclepiadeæ," Trans Linn. Soc., vol. xvi., 1833; reprinted in "Miscellaneous Botanical Works," vol. i. p. 5 Ir. Ray Society edition.

3 Fontana (op.cit.) figured the "globules" or scales of the epidermis, in which he recognized the nucleus, but he neither gave it a special name, ncr knew iłs importance (Plate i., Figs. 8, 9, 10.)

4 "Mikroskopische Untersuchungen," 1839; and preliminary notices in Froriep's Notizen, $188_{3} 8$. 
contents that were either fluid or somewhat more consistent. Either attached to the wall or embedded in it was the nucleus, which in its turn contained the nucleolus. Schwann, however, recognized (p. 176 of Sydenham Society's translation of Schwann's memoir) that many cells did not exhibit any appearance of a cell-membrane, but seemed to be solid, and had their external layer somewhat more compact. As showing, however, the importance which Schwann attached to the cell-wall, I should state that he regarded the chemical changes or metabolic phenomena as he termed them, as being chiefly produced by the cell-membrane, though the nucleus might participate. He explained the distinction between the character of the cell contents and the cytoblastema external to the cell, to the power exercised by the cell-membrane of chemically altering the substances which it is either in contact with or has imbibed, and also of separating them so that certain substances appear on the inner and others on the outer surface of that membrane. In this way, he accounted for the secretion of urea by the cells lining the uriniferous tubes, and for the changes which not unfrequently take place in the cell-membrane itself by thickening or deposition of layers on or within it.

Schwann described the nucleus as either solid or hollow and vesicular, in the latter case being surrounded by a smooth structureless membrane; whilst the contents of the nucleus, other than the nucleoli, were in his view either pellucid or very minutely granulous.

Both Schleiden and Schwann conceived that in the formation of a nucleus a nucleolus was first produced, that around it new molecules were deposited for a certain distance, and then a nucleus was formed. When the nucleus had reached a certain stage of development, new molecules were deposited upon its exterior so as to form a stratum, which when thin was developed into a cellmembrane, but when thick only its outer portion became consolidated into a cell-membrane. Immediately the membrane became consolidated its expansion proceeded by the progressive reception of new molecules ; the cellwall separated from the cell nucleus, and a vesicle was formed; the intermediate space at the same time became filled with fluid, which constituted the cell contents.

Schleiden contented himself with little more than a simple statement of what he conceived to be the process of cell formation in plants; but Schwann entered into an elaborate survey of cell-life both in animals and plants, and founded on it a theory of cells applicable to all organisms.

Schwann conceived that there existed in organized bodies a solid amorphous or fluid substance to which he gave the name cytoblastema; this substance might be contained either within cells already existing, or else be situated in the interspaces between cells ; and he believed that the cytoblastema for the lymph and blood corpuscles is the fluid lymph-plasma and liquor sanguinis in which these corpuscles float. He held that in the cytoblastema new cells are formed in the manner just described. In animals he says it is rare for cells to arise within preexisting cells ; more usually they arise in a cytoblastema external to the cells already present. Schleiden, on the other hand, maintained that in plants new cells were never formed in the intercellular substance, but only within preexisting cells. The idea obviously present in the mind of Schwann was that the process of cell formation in a cytoblastema had some affinity with that of crystallization. He figuratively compares the cytoblastema to a motherliquid in which crystals are formed. He speaks of molecules being deposited around a nucleolus to form a nucleus; of a nucleus growing by a continuous deposition of new molecules between those already existing; and of the cell being formed around the nucleus by a progressive deposition of new molecules; and in more than one passage he indicated that this deposition is a precipitation. $\mathrm{He}$ obviously considered the principle of formation of the cell around the nucleus as the same as that of the nucleus around the nucleolus, a process which Valentin subsequently described as heterogeneous circum-position.

But Schwann at the same time showed that, with reference to the plastic phenomena, cells differed from crystals in form, structure, and mode of growth ; for whilst a crystal increases only by the external apposition of new particles, a cell grows both by that method and by the intussusception of new matter between the particles already deposited. The difference, he says, is yet more marked in the metabolic phenomena, which he conceived to be quite peculiar to cells. Cells and crystals, however, he considered resembled each other in this point, that solid bodies of a definite and regular shape are formed in a fluid at the expense of a substance held in solution by that fluid, for both attract the substance dissolved in the fluid. Schwann concluded his memoir by advancing, as a possible hypothesis, the view that organisms are nothing but the form under which substances capable of imbibition crystallize; and although this hypothesis involved very much that is uncertain and paradoxical, yet he considered it to be compatible with the most important phenomena of organic life. Schwann inclined, therefore, to a physico-chemical explanation of cell-formation and cellgrowth.

Shortly after the publication of Schwann's famous memoir, Henle, who had for some years been engaged in microscopic investigations on the tissues, published his well-known treatise on general anatomy. ${ }^{1}$ He attached great importance in cell formation to extremely minute particles, $\frac{\pi}{6000}$ to $\frac{1}{2000}$ of an inch in diameter, which he called elementary granules. He conceived that these appeared in a blastema, that several aggregated together to form a nucleus, in connection with which he thought it not improbable that a cell subsequently formed. He looked upon the elementary granules as the first and most general morphological elements of the animal tissues, and he regarded them as vesicles consisting of excessively minute particles of oil coated with a film of albumen. It should be stated that Henle's observations on cell formation were conducted to a large extent on the products of inflammation, and on the lymph and chyle, in all of which fatty and granular particles abound.

As regards the part which the nucleus plays in the process of cell formation, both Schleiden and Schwann regarded it as of prime importance, though in the subsequent life of the cell they considered that its function terminated. Schleiden stated that, subject to certain exceptions which he enumerated, it is rare for the cytoblast to accompany the cell through its entire vital processthat it is often absorbed either in its original place, or cast off as a useless member, and dissolved in the cavity of the cell. Schwann, whilst contending for the exceedingly frequent, if not absolutely universal, presence of the nucleus, yet held that in the course of time it usually became absorbed and disappeared, so that it had no permanent influence either on the life of the cell or the reproduction of young cells, though he recognized that it remained in the blood corpuscles of some animals. Henle, again, maintained that, as there are nuclei without nucleoli, so also cells exist without nuclei, and that new cells may arise without the least trace of cytoblasts.

At about the same time, and also immediately after the publication of the important investigations by these eminent German observers, a young graduate of medicine of the University of Edinburgh, Dr. Martin Barry, stimulated, he says, by the researches and encouraged by the friendship of Johannes Müller, Ehrenberg, Rudolph Wagner, and Schwann, undertook elaborate researches into the structure of the ovum, more especially in mammals. His results were published in a series of memoirs printed in the Transactions of the Royal Society

I “Allgemeine Anatomie," Leipzig, r84r; also French translation by Jourdan in "Encyclopédie Ánatomique," vols. vi., vii., Paris, 1843 . NO. IO97, VOL. 43$]$ 
of London from 1838 to $184 \mathrm{I}^{1}$ In these embryological memoirs, Barry announced several important discoveries. In his first memoir (1838) he pointed out that the germinal vesicle which had been discovered in the mammalian ovum by M. Coste and Mr. Wharton Jones was the first part of the ovum to be formed both in mammals and birds, and he thought that this was probably the case throughout the animal kingdom. In his second memoir (I 839) he extended to the mammalian ovum an observation which had been made by Prevost and Dumas on the ovum of the frog, and by Rusconi on the ovum in osseous fish. He described the formation within the rabbit's ovum of the body which he named, and which has been known since his time as the mulberry-like structure. This body arose at first as two vesicles, then as four, and so on in multiple progression, so that Barry was the first to recognize in the ovum of mammals the process which we now know as the segmentation of the yelk. He showed that the vesicles of the mulberry body were cells, and that each contained a pellucid nucleus, and that each nucleus presented a nucleolus. Further, these vesicles arranged themselves as a layer within the zona pellucida.

Barry's third memoir was published in 1840 , and as he gave it the subsidiary title of "A Contribution to the Physiology of Cells," it is clear that he regarded his embryological inquiries as having an important bejaring on the facts of cell-formation and function. He repeated his observations on the formation of the mulberry-like body, and now recognized that its component cells had been derived from the germinal vesicle, the contents of which entered at first into the formation of two cells, each of which presented a nucleus which resolved itself into other cells, and by a repetition of this process, the cells within the ovum became greatly augmented in number. Further, he stated that the whole embryo at a subsequent period is composed of cells, filled with the foundations of other cells. Although we may not agree with all the details given by Barry in his account of these observations, yet there can be no doubt that he had early recognized the important fact, that in animals new cells arose within pre-existing cells, as Schleiden had affirmed to be the case in plants, and that the nucleus acted as an important centre for the production of young cells. In recognizing the endogenous reproduction of young cells in animals, Barry made an important advance on the view entertained by Schwann, who regarded the endogenous production of cells as quite exceptional amongst animals.

In this same memoir Barry incidentally mentioned that he saw in the ovum of the rabbit a cleft or orifice in the zona pellucida, and that on one occasion he observed what he believed to be the head of a spermatozoon within the orifice. Two years afterwards he read to the Royal Society (Phil. Trans., vol. cxxxiii. ; read December 8, 1842) a short paper, in which he announced that he had seen a number of spermatozoa within the ova of the rabbit, and in October 1843 he published a figure of an ovum with spermatozoa in its interior ("On Fissiparous Generation," Edin. New Phil. Journ., October 1843).

In a memoir on the corpuscles of the blood, published in $\mathrm{I} 84 \mathrm{I}$, Barry announced a still more definite conception of the function of the nucleus. He directly traversed the statement of Schleiden, that the nucleus, after baving given origin to the cell-membrane, has performed its chief office, and is usually cast off and absorbed; as well as that of Schwann, who had never, except in some instances in fat-cells, observed anything to be produced by the nucleus of the cell. Barry stated that the nucleus is a centre for the origin, "not only of the transitory contents

${ }^{3}$ Phil. Trans., vols. cxxviii.-cxxxi. The value which was attached to these memoirs at the time may be estimated by the fact that the Royal Society of London awarded to their author in $1839 \mathrm{cne}$ of the Royal Medals. The neglect into which Dr. Barry's writings have since fallen is largely due The neglect into which Dr. Barry's writings have since fallen is largely due
to the disbelief in his subsequent descriptions of the spiral structure of muscular fibre, of blood-corpuscles, and indeed of the elements of the tissues guscular

No. IC97, voL. 43] of its own cell, but also of the two or three principal and last formed cells destined to succeed that cell; and in fact, that by far the greater portion of the nucleus, instead of existing anterior to the formation of the cell, arises within the cavity." Further, he says, "young cells originate through division of the nucleus of the parent cell, instead of arising as a sort of product of crystallization in the fluid cytoblastema of the parent cell." $\mathrm{He}$ regarded the division of the nucleus in pus corpuscles as not artificially produced by the agency of acetic acid, as was held by Henle and Schwann, but as a part of the process by which cells were produced, and apparently universal in its operation.

In a paper published in 1847 , Dr. Barry summarized his observations on the nucleus of animal and vegetable cells, and whilst expressing certain opinions on the mode of formation of the nucleolus and nucleus and the growth of cells which cannot now be accepted, he continued to maintain that cells are descended from an original mother cell by cleavage of the nucleus, and all subsequent nuclei are propagated in the same way by fissiparous generation. Every nucleus, therefore, was a sort of centre, inheriting more or less the properties of the original nucleus of the fecundated ovum, which he conceived to be the germinal spot, and exercising an assimilative power. Dr. Barry's contributions to a correct conception of the development of cells are of the highest importance when viewed in the light of modern observations.

But another Edinburgh inquirer, Mr. John Goodsir, afterwards as Prof. Goodsir the distinguished occupant of the Chair of Anatomy in the University of Edinburgh, was engaged between the years 1842 and 1845 in studying the processes of cell-life, both in healthy tissues and in certain pathological conditions. ${ }^{1}$ In his important memoir on secreting structures, published in 1842 , he demonstrated from a variety of examples that secretion is a function of the nucleated cell, and he gave, as one of his many illustrations, the cells of the testis containing spermatozoa which were derived from the nuclei of these cells. In the original memoir he was inclined to believe that the cell wall was the structure engaged in forming the secretion; but in a reprint of it in 1845 , he modified that view, and gave as his opinion that the secretion would appear to be a product of the nucleus. Goodsir also stated in the memoir of 1842 "that the nucleus is the reproductive organ of the cell, that it is from it, as from a germinal spot, that new cells are formed," and he cited cases in which it became developed into young cells. $\mathrm{He}$ subsequently, in a short paper on centres of nutrition, extended this view to the tissues generally. He defined the nutritive centres as minute cellular parts, existing, for a certain period at least, in all the tissues and organs. They drew from the capillary vessels or other sources nutritive material, which they distributed to the tissues and organs to which they belonged. He regarded a nutritive centre as a cell, the nucleus of which is the permanent source of successive broods of young cells, which from time to time fill the cavity of their parent. He called this central or capital cell the mother of all those within its own territory or department. Goodsir also showed that cells were important agents in absorption, ulceration, and inflammation. In inflammation of cartilage, for example, he described and figured the cells in the area affected as increased in size, modified in shape, and crowded with a mass of nucleated cells in their interior, through the agency of which the walls of the corpuscles and the hyaline matrix became absorbed. $\mathrm{He}$ also gave illustrations of the multiplication of nuclei within cells in the course of formation of cysts. Corroborative observations on endogenous formation within

x “On Secreting Structures," Trans. Roy. Soc. Edin., 1842 ; “On Peyer's Glands," London and Edinburgh Monthly Journal, April r842; "On Structure of Human Kidney," ibid., May 1842; "Anatomical and Pathological Observations," "Edinburgh, 1845; also, his collected papers in "Anatomical Memoirs," Edinburgh, z868, edited by W. Turner. 
animal cells were also given by Mr. H. D. S. Goodsir, as confirmatory of the doctrine propounded by his brother on the cell as a centre of nutrition, secretion, and production of young cells. In a research into the structure of the testis in Decapodous Crustacea, Henry Goodsir observed that the head of the spermatozoon corresponded with the nucleus.

The conception entertained both by Martin Barry and John Goodsir of the process of cell-formation and of the function of the nucleus was in the main very different from that propounded by Schleiden and Schwann. Whilst agreeing with Schleiden in holding that new cells were formed within parent cells, they did not look upon the process as one of deposition, in the first instance around a nucleolus and then around a nucleus, but they regarded the nucleus as the prime factor by the division of which new cells were formed. With regard to the free formation of cells, as it was not unfrequently called, by deposition in a cytoblastema situated externally to existing cells, to which Schwann and Henle attached so much importance in animals, they gave no concurrence. Both Barry and John Goodsir had grasped and advocated the fundamental principle, both of the endogenous development of cells from a parent centre and of an organic continuity between a mother cell and its descendants through the nucleus ; and the brothers Goodsir had applied this principle in their anatomical, pathological, and zoological researches.

As regards the physiological action of cells, Mr. (now Sir William) Bowman had expressed the opinion ${ }^{1}$ that there was a strong presumption that the epithelium of glands assimilated the secretion from the blood; that the secretion might be separated, either by the passage of its elements through the cells, or by the cells undergoing solution or deliquescence, or by the cells being cast off entire with their contents. Mr. (now Sir John) Simon also expressed, in I 845 , some important general conclusions on the physiological action of cells (" Essay on the Thymus Gland," London, 1845). He looked upon the cell wall as of secondary importance and of inessential formation, and he regarded the nucleus with the material developed around it as constituting the sole physical evidence of activity in the part. He saw bile and other secretions within cells, and stated that when the products of secretion can be seen within a cell, they are accumulated in the portion which corresponds to the nucleus as though it were the true centre of attraction. Simon also observed the development of spermatozoa within cells, and had seen one end adhering to the relique of a cell, probably its nucleus.

Histologists elsewhere had made isolated observations on the development in the animal body of young cells within parent cells. Even before the publication of Schwann's immortal treatise, Turpin had stated that the corpuscles which he found in vaginal discharges contained a new generation in their interior, and Dumortier had described secondary cells as formed in the ova of snails. These observations exercised, however, no influence on the progress of thought; and Schwann, though referring to them in the preface to his treatise, yet ap peared to question their accuracy.

In $184 \mathrm{I}$, Robert Remak published (Medicinische Zeitung, p. 127, July 7, I841) an account of what he saw in the blood corpuscles of the chick, some of which were biscuit-shaped. At each end was a nucleus, and the two nuclei were connected together by a thin stalk which traversed the intermediate part of the corpuscle. He thought it probable from these observations that a multiplication of blood corpuscles through division occurred. He obtained also similar evidence in the blood of the embryo pig, and saw, both in the blood of the horse and of man, red blood-cells formed in the interior

\footnotetext{
r Article "Mucous Membrane," in Todd's "Cyclopadia," date probably
} 1842 or 1843 .

NO. IO97, VOL. 43] of large mother cells. It is customary in Germany to credit Remak with being the first to recognize the division of the nucleus within the cell as a stage antecedent to, and associated with, the division of the cell itself; but from what has already been stated, it will be seen that Martin Barry had preceded him by some months ${ }^{1}$ in the recognition of the importance of division of the nucleus in the production of young cells.

In 1843, Albert von Kölliker published (Müller's Archiv, 1843) an interesting memoir on the changes which take place in the fertilized ova of various parasitic worms. He described and figured the production in regular progression of young cells within the ovum, and observed that in some cells the nucleus was elongated ; in others constricted in the middle, as if about to divide ; in others two nuclei were present, each smaller than the single nucleus of adjoining cells, as if they had arisen from the division of a larger nucleus. A legitimate inference from these cbservations was that, in the formation of young cells, the nucleus of the parent cell divided into two, and that each of these gave origin to a new cell.

The endogenous multiplication of animal cells by division of the nucleus now began to be more widely recognized. It was described by Kölliker and by Mr. (now Sir James) Paget in the blood corpuscles of the embryo, by Kölliker in cartilage and in the giant cells of the marrow of bones, and by various observers in the fertilized ovum. It acquired, therefore, much more importance as a mode of origin of animal cells than was accorded to it by Schwann.

At the time when I began the study of anatomy and physiology in I850, the current teaching of the schools embraced two methods of cell-formation - the one through the intermediation of existing cells, which might be either by endogenous production within a mother cell through division of the nucleus, or by fissiparous division, or by budding off of a part of a cell ; the other by a process of free cell-formation outside existing cells and within a blastema. When I came to Edinburgh in 1854 to act as Demonstrator of Anatomy, I found that the biologists were divided into two hostile forces-the one was presided over by Prof. John Goodsir, whose views on the intracellular origin of new cells I have already explained, and which he systematically expounded in his lectures; the other was led by the then Professor of the Institutes of Medicine, Dr. Hughes Bennett. Dr. Bennett, whose investigations into cell-formation and cell-life had been largely based, like those of Henle, on the study of pathological processes, was led to attach great importance to the granules or molecules which abound in the so-called inflammatory exudations and in purulent fluids. Bennett held that molecules arose in an organic fluid, and that an aggregation of molecules produced nuclei, upon which cell walls may be formed; that the molecule was the primary, elementary, and most simple form of organized matter, and that an aggregation of molecules might even form fibres and membranes without the agency of cells. His views were almost a reproduction of those of Henle, and he advocated them with great vigour and persistency, especially in regard to the production of pus and other products of inflammation.

Pathologists had indeed very generally supported the

I Barry's later mem irs were read to the Royal Society of T.ondon, May.7 $184^{\circ}$; January $7,184 \mathrm{I} ;$ June 17 and $23,184 \mathrm{r}$. Thev are illustrated with numerous beautiful figures, in wh.ch the dision of the nucleus and the numerous beattiful higures, in wh.ch the dirion enrogenous production of young cells are shown. Further, it should be $\mathrm{kr}$ p in mind that kenak's ibservation was on a single rissue, the embryonic blood corpuscle; whilst Barry's was a general zation based on a large series of researches on the ovum, blood and mucous corpuscles, epithelium and other cells. John Goodsir, in a footnute to his important paper "On Centres of Nutrition," already referred to, says :- "For the first consistent account of the development of cells from a parent centre. and more especially of the appearance of new centres within the original sphere, we are indebted to the researches of Dr. Martin Barry." Remak subsequently extended his observations, on the multiplication of cells through division of the nuclei, to the ovum, and the cells of the tissues generally. See Miuller's Archiv, 1852, p. 47, and "Untersuchungen über die Entwicklung der Wirbelthiere," 1855 . 
theory of the free formation of cells in exudations; but this view, however, was not universally entertained by them. Prof. Goodsir (op. cit., r845), and Dr. Redfern ${ }^{1}$ had shown its inapplicability in inflammation and ulceration of articular cartilages. Prof. Virchow, in a series of papers in his Archiv, commencing with vol. i. in 1847, had described the endogenous formation of young cells in pathological structures. In his "Lectures on Cellular Fathology," published in 1858, Virchow, like Goodsir, announced his belief in the mapping out of the body into cell territories. Virchow's conception of the territory was the intercellular substance immediately surrounding a cell, and subject to its influence. ${ }^{2} \mathrm{He}$ maintained that in pathological structures there was no instance of development de novo, but that where a cell existed, there one must have been before. He called it the law of continuous development, which could be formulated in the expression omnis cellula e cellula. He adduced a great variety of specific instances to show the diffusion throughout the tissues and organs of nucleated cells, and he established, by a variety of proofs, the important part played by the cell elements, more especially those of the connective tissue, in the inflammatory process and in the production of new formations. He advanced, indeed, such a mass of evidence in support of this position, that the theory of free cellformation was shortly after abandoned in connection with pathological processes, as it had been some time previously by most observers in normal histogenesis. ${ }^{3}$

(To be continued.)

\section{THE CAUSES OF ANTICYCLONES AND}

\section{CYCLONES}

A

MEMOIR presented to the Vienna Academy of Sciences on April I7 last by Prof. J. Hann, giving the results of his study of an anticyclone which lay over Central Europe from November 12 to 24, I8x $9,{ }^{4}$ brings to a climax one of those investigations that rank as landmarks in the advance of science, and compels us to modify in some important particulars the views now generally current on some of the leading phenomena in meteorology. Next to the facts of the general circulation of the atmosphere, which, in recent years, have been treated of more particularly by Ferrel, Hann, Siemens, Sprung, Oberbeck, and Pernter, the relations between areas of high and low pressure, or anticyclones and cyclones, have played a chief part in the science of atmospheric movements; and indeed in that large and popular department that deals with the weather and its vicissitudes, they may be said almost to monopolize the field. Hitherto, however, excepting in so far as the movements of the clouds afford us any information of the changes in progress in the higher atmosphere, our experiential knowledge of cyclones and anticyclones has been almost restricted to what can be observed within a small distance of the general land-surface. As a rule, a region of hish barometer, especially in the winter, is one of low surface temperature, while cyclones, which originate in regions of low pressure, are fed by warm southerly winds. Interpreting these facts by the light of well-known physical laws, it has become the common teaching of our text-books that the former are due to the low mean temperature and therefore increased density of the superincumbent air column, while the Iatter are

× "Abnormal Nutrition in Articular Cartilages," Edinburgh Monthly Medical fournal, August 1849: and separate memoir, Edinburgh, 1850 . ${ }^{2}$ He first used the term "Zellen Territorien" in his Archiv, Bd. iv., ${ }^{8} 8_{52}$, p. 383 . 3 In a lecture which I delivered before the Royal College of Surgeon Edinburgh, in $186_{3}$ (Edinburgh Medical Journal, April 1863), I summarized the evidence of the derivation of pathological cell formations from preexisting cells. and adduced additional examples from my uwn observations. 4. Das Luftdruck Maximum von November 1889 in Mittel Eurupa nebst Bemerkungen ueber die Barometer-maxima in Allgemeinen," von J. NO. IO97, VOL. 43] brought ahout by the opposite conditions. The correctness of these views, in so far, at. least, as regards anticyclones, was challenged by Dr. Hann as long ago as 1875, in a paper published in the Vienna Zeitschrift (vol. x. p. 210), wherein he showed that, as a result both of theory and observation, the cold that prevails in a region of high barometer in winter is really due to terrestrial radiation under the clear skies that are characteristic of such an area, that it is restricted to a stratum of very moderate thickness, and that above this the compression of the sinking atmosphere must induce a high temperature, and consequently greatly reduce its density.

In a subsequent, very suggestive paper, published in I 879 in the fourteenth volume of the same periodical, he discussed more fully the causes of anticyclones, and concluded that they are essentially the same as those which give rise to the two sub-tropical zones of high barometerviz. the congestion of the upper or anti-trade currents, directed polewards and eastwards, which, owing to the rapid contraction of the circumpolar zones in high latitudes, are partially arrested and forced to return in a lower stratum of the atmosphere. He also expressed the opinion that these areas of congested currents determine the formation of travelling cyclones in the intervals of relatively low pressure, instead of being themselves caused by the overflow of the upper currents from the latter (which is Ferrel's view). Hence that both anticyclones and cyclones have their origin in the circumstances of the general atmospheric circulation, and are, in neither case, primarily due to the heating or cooling of that part of the earth's surface which they temporarily occupy. Some further consequences of high importance were pointed out in this essay. Since the general circulation of the atmosphere is determined by the expansion of the air over the equatorial zone, and the consequent tilting of the planes of equal pressure to form a gradient between the equator and the two poles, the greater frequency of stormy weather in the higher latitudes in winter was shown to follow from the increased activity of the higher or anti-trade currents ; the difference of temperature between equatorial and polar and sub-polar regions being at that season at their maximum; and not merely to the contrasted conditions of continents and oceans. Also that any cause tending to increase the heating and expansion of the equatorial atmosphere must intensify both the anticyclonic and cyclonic movements of the temperate and sub-polar zones. In another paper, published in the fifteenth volume of the Zeitschrift, he pointed out that this last view received confirmation from the fact, then recently ascertained, that those years in which the barometer ranged below the average in the Indo-Malayan region were years of excessive barometric pressure in winter (but not in summer) in Western Siberia and Russia.

From time to time, as occasion has served, Prof. Hann has continued to verify these views, by investigating the temperature conditions of anticyclones, on the evidence afforded more particularly by the high Alpine and other mountain observatories. He has thus shown that the relatively high temperature prevailing at high levels during periods of intense winter cold at low levels is no exceptional occurrence, but a constant and characteristic feature of anticyclonic conditions. Moreover, that, as a general fact, the temperature at mountain observatories in winter rises and falls directly with the barometric pressure at those elevations, while the reverse holds good at the general ground surface. In summer, the lowest temperatures at mountain observatories coincide also with the lowest pressures at the ground surface; and this he explains partly by the fact that a low barometer is accompanied with stormy and rainy weather, and with snow at the greater elevations, and partly by the dynamic cooling of the ascending air over the region of minimum pressure. The Alpine observatories are, however, less favourably situated for 